\title{
Görev Temelli Yeni Bir Stokastik Çok Kriterli Karar Verme Yaklaşımı Önerisi
}

\author{
Pelin Toktaş ${ }^{1}$, Gülin Feryal Can ${ }^{2 *}$ \\ ${ }^{1}$ Başkent Üniversitesi, Mühendislik Fakültesi, Endüstri Mühendisliği Bölümü, Ankara, Türkiye (ORCID: 0000-0001-6622-4646) \\ 2 Başkent Üniversitesi, Mühendislik Fakültesi, Endüstri Mühendisliği Bölümü, Ankara, Türkiye (ORCID: 0000-0002-7275-2012)
}

(İlk Geliş Tarihi 10 Aralık 2019 ve Kabul Tarihi 22 Şubat 2020)

(DOI: 10.31590/ejosat.657719)

ATIF/REFERENCE: Toktaş, P. \& Can, G. F. (2020). Görev Temelli Yeni Bir Stokastik Çok Kriterli Karar Verme Yaklaşımı Önerisi. Avrupa Bilim ve Teknoloji Dergisi, (18), 61-75.

\begin{abstract}
Öz
Gerçek hayattaki karar problemlerinde genellikle, karar konusuyla ilgili yeterli düzeyde bilgi ve deneyime sahip sınırlı sayıda uzmanın görüşlerinden yararlanılarak sonuca ulaşılmaktadır. Çalışmada, karar verme süreçlerinde uzman sayılarının arttırılmasıyla yeni görüşlerin elde edilebilmesine ve uzman değerlendirmelerindeki belirsizliğin rassallık dikkate alınarak gerçek hayata uygun bir şekilde modellenebilmesine imkan tanıyan yeni bir Çok Kriterli Karar Verme (ÇKKV) yaklaşımı önerilmiştir. Bu kapsamda, farklı bakış açılarıyla alternatif sıralamalarını elde etmeyi sağlayan Oran Analizi Temeline Dayalı Çok Amaçlı Optimizasyon Yöntemi (The Multi-Objective Optimization by Ratio Analysis Method-MOORA) kapsamındaki iki farklı yöntem, sürekli düzgün dağılım kullanılarak geliş̧irilmiştir. Bu yaklaşımlar, MOORA Oran ve MOORA Referans Noktası yaklaşımlarıdır. Sürekli düzgün dağılım, belirli bir aralıkta yer alan her bir değerin ortaya çıkma şansının eşit olması nedeniyle tercih edilmiştir. Bu durum, farklı uzman görüşlerinin her birine eşit şans verilmesi anlamını taşımaktadır. Buna göre, sınırlı sayıda uzmanın görüşleri kullanılarak, sürekli düzgün dağılımla rastgele sayılar üretilip; kriter ve alternatiflerin değerlendirmelerine ilişkin sonuçlar arttırılabilir. Her bir farklı değerlendirme, bir uzmanı temsil etmektedir. Rastgele sayılar, mevcut uzmanların en yüksek ve en düşük değerlendirmeleri dikkate alınarak, söz konusu aralıkta üretilmiştir. Bunun sebebi ise, karar konusuna ilişkin bir ön değerlendirme elde etmektir. Bununla birlikte, önerilen yaklaşım görev temelli bir yaklaşım olup, karar vericiler alternatifleri değerlendirmeden önce ilgili alternatiflerin kullanımını gerçekleştirmektedirler. Bu kullanım esnasında, karar vericilere uygulamaya dönük farklı görevler verilmektedir. Görevlerin gerçekleştirilme etkinliği, karar vericilerin gerçek kullanıcıların ihtiyaçlarını anlamalarını sağlamakta ve farklı bir bakış açısıyla alternatifler değerlendirilebilmektedir. Çalışmada alışveriş merkezlerinin değerlendirilmesi kapsamında dikkate alınan evrensel tasarım prensipleri ve kullanıcı mennuniyeti kriterleri açısından da önerilen görev temelli ÇKKV yaklaşımı önem taşımaktadır. Geliştirilen iki farklı MOORA yaklaşımı, alışveriş merkezlerinin evrensel tasarım prensipleri ve kullanıcı memnuniyeti kriterleri dikkate alınarak değerlendirilmesi için uygulanmış ve elde edilen alternatif sıralamaları tartışılmıştır. Ayrıca, söz konusu iki farklı yaklaşımın, kriterlerin önem ağırlıklarını da hesaplayabilecek şekilde geliştirilmesi de sağlanmıştır. Gerçekleştirilen çalışma, önerilen yeni yaklaşım ve alışveriş merkezlerinin değerlendirilmesinde dikkate alınan kriterler açısından orjinallik içermektedir.
\end{abstract}

\section{A New Task-Based Stocastıc Multi-Criteria Decision Making Approach}

\begin{abstract}
In real life decision problems, the result is generally obtained by using the opinions of a limited number of experts who have sufficient knowledge and experience on the subject of the decision. In the study, a new Multi Criteria Decision Making (MCDM) approach was proposed, which enables new views to be obtained by increasing the number of experts in decision-making processes and modeling
\end{abstract}

\footnotetext{
* Sorumlu Yazar: Başkent Üniversitesi, Mühendislik Fakültesi, Endüstri Mühendisliği Bölümü, İstanbul, Türkiye, ORCID: 0000-0002-7275-2012, gfcan@baskent.edu.tr
} 
uncertainty in expert evaluations in a real-life manner. In this context, two different methods, which are based on the The MultiObjective Optimization by Ratio Analysis (MOORA) Method, are developed using continuous uniform distribution. These approaches are MOORA Ratio and MOORA Reference Point approaches. Continuous uniform distribution was preferred because each value within a certain range had an equal chance of occurrence. This means that each expert opinion is given an equal chance. Accordingly, by using a limited number of experts' opinions, random numbers are generated with continuous uniform distribution; the results of the evaluation of criteria and alternatives can be increased. Each different assessment represents an expert. Random numbers were generated within this range, taking into account the highest and lowest assessments of current experts. The reason for this is to obtain a preliminary assessment of the decision. However, the proposed approach is a task-based approach and decisionmakers make use of relevant alternatives before evaluating them. During this use, decision makers are given different practical tasks. The efficiency of performing tasks enables decision-makers to understand the needs of real users and can be evaluated from a different perspective. The task-based MCDM approach is also important in terms of universal design principles and user satisfaction criteria considered in the evaluation of shopping centers in the study. Two different MOORA approaches have been applied in order to evaluate the shopping centers considering universal design principles and user satisfaction criteria and the alternative rankings obtained have been discussed. In addition, these two different approaches were developed to calculate the importance weights of the criteria. The study involves originality in terms of the proposed new approach and the criteria considered in the evaluation of shopping centers.

Keywords: MOORA Ratio, MOORA Reference Point, Uniform Distribution.

\section{Giriş}

Alışveriş merkezleri, insanların her türlü ihtiyacını karşılamaya yönelik kurulmuş olan yaşam alanları olarak kabul edilmektedir. Bu alanlarda çocuklar, yaşlılar, engelliler gibi farklı özelliklere sahip birçok insan için kaliteli bir şekilde zaman geçirmeyi sağlayan birçok imkân bir arada bulunmaktadır. Bununla birlikte, içerisinde yer alan çok sayıdaki mağazada, toplumun farklı kesimlerinin ihtiyaçlarını karşılayabilecek ürünler yer almaktadır. İnsanlar, alışveriş merkezlerinde hem ihtiyaç duydukları ürünlere ulaşabilmekte, hem eğlenebilmekte ve dinlenebilmektedirler. Bu nedenle alışveriş merkezleri, toplumun geneli ile etkileşim içerisinde olan kamusal alanlar arasındadırlar. Alışveriş merkezlerinin devamlılığı, çok sayıda kişi tarafından ziyaret edilebilmelerine bağlıdır. Bu açıdan, alan tasarımının engelli, yaşlı, çocuk, hamile ve gençlerin bir bütün olarak düşünülmesiyle yapılması önem taşımaktadır. Aksi halde, toplumun geneline hitap edemeyeceklerdir. $\mathrm{Bu}$ durum, perakende pazarındaki başarılarını olumsuz etkileyecek ve ekonomik mevcudiyetlerini de tehlikeye sokacaktır. Bunu önlemek için, toplumda var olan farklı özelliklerdeki bütün insanların kolaylıkla erişebileceği ve kullanabileceği alan tasarımlarına sahip olmaları gerekmektedir. Bununla birlikte, farklı engelleri olan insanların sosyal hayata kazandırılabilmeleri açısından da, alan tasarımı önemli bir yere sahiptir.

Engelli insanlar, doğumla ilgili hatalar, trafik kazaları, iş kazaları veya hastalık gibi nedenlerle, normal insanların işlevlerini gerçekleştirememektedir. Zihinsel, ruhsal, duygusal veya sosyal açılardan yaşamlarını bir engelle birlikte sürdürmektedirler. Birtakım yardımcı alet ve cihazların desteğiyle gerçekleştiremedikleri işlevlerini yerine getirmeleri mümkün olabilmektedir. Bununla birlikte, sadece engelli bireyler değil yaşlı bireyler için de gün içerisindeki birçok aktiviteyi gerçekleştirmek zor olmaktadır. Aynı durum, çocuklar ve hamileler için de geçerlidir. Bu açıdan, toplumun bir parçası olan bu tür insanların ihtiyaçlarını da gözeterek kullanılan her türlü, alan, cihaz, eşya vb.nin tasarımı gerçekleştirilmelidir. Söz konusu çok boyutlu tasarım yaklaşımının temelleri 1980’lerin ortalarında hayat bulmaya başlayan, "evrensel tasarım”, "herkes için tasarım” konseptidir. Evrensel tasarım, tüm ürünlerin ve çevrelerin, yaş, beceri ve durum farkı gözetmeksizin bütün insanlar tarafından kullanılabilmesini sağlayan bir tasarım yaklaşımıdır (Meyer ve Fourie, 2016). Evrensel tasarım, yedi prensip dikkate alınarak gerçekleştirilir. Bu prensipler, eşitlikçi kullanım (EK), kullanımda esneklik (KE), basit ve sezgisel kullanım (BSK), algılanabilir bilgi (AB), hata için tolerans (HT), düşük fiziksel güç gereksinimi (DFGG), yaklaşım ve kullanım için uygun boyut ve mekân (YKUBM)'dır (Story, 1998). EK prensibi, farklı özellikteki ve yetkinlikteki kullanıcılar için tasarımda eşit şartların sağlanması anlamını taşımaktadır. Güvenlik ve mahremiyet ile ilgili kurallar tüm kullanıcıları kapsamalı ve farklı özellikteki kullanıcılar damgalanmamalıdır. KE prensibinde tasarımın, farklı kullanım biçimlerini içerisinde barındırması hedeflenmektedir. Örneğin bir ürünün, sağ ve sol elini kullananlar için aynı derecede kolay kullanılabilir olması gibi ya da ürünün, kullanıcının farklı hızda algılamasına olanak sağlaması gibi. BSK, tasarımın kullanıcının tecrübe, bilgi, dil becerisi ve anlık odaklanma düzeyinden bağımsız olarak kolay anlaşılabilir olmasını gerektirmektedir. Ürün karmaşık bir kullanım sürecine sahip olmamalı, insan algı ve sezgilerine ters yönde işlememelidir. Ürün üzerinde yer alan simge, renk, yazı vs., farklı özellikteki insanların okuma düzeyi ve dil becerisini kapsamalı ve geri bildirim sağlayabilen bir tasarım olmalıdır. AB'de, tasarımın kullanıcı için gerekli bilgiyi etkin bir biçimde sunması beklenmektedir. Tasarım üzerindeki temel bilgiler kolaylıkla okunabilir olmalıdır. Ürünün özellikleri kullanıcının kolay anlayabileceği şekilde farklılaştırılmış olmalıdır. Ürün, özellikle duyusal engelleri olan kullanıcılar için, uyumu sağlayacak teknikleri ya da ara yüzleri içermelidir. HT'de, tasarımın kullanım sonucu ortaya çıkabilecek tehlikeli ve kötü sonuçları en aza indirmesine dikkat edilmektedir. Buna göre, kaza ve hatalara sebep olabilecek uygulama şekilleri ve tasarım bileşenleri açık olarak belirtilmiş olmalıdır. Hataların ortaya çıkmasını engelleyen tasarım özellikleri sağlanmalıdır. DFGG kapsamında, tasarımın rahatlıkla kullanılabilir olması, kullanım sürecinde yorgunluğu en alt seviyeye indirmesi amaçlanmıştır. Ürün, kişileri zorlamayacak seviyede güç kullanarak çalıştırılabilmelidir. YKUBM ise, kullanıcının vücut ölçüleri, duruş pozisyonu ve hareketlilik seviyesine bağlı olmadan yaklaşma, uzanabilme, elle kullanım ve genel kullanım için uygun boyut ve alanın sağlanmış olması anlamını taşımaktadır. Ayrıca, tekerlekli sandalye, yürüme gereçleri, vb. destek araçlarının veya yardımcı olacak kişilerin hareketi için de yeterli alan sağlanmalıdır (Story, 1998).

Çalışmada, birbirine yakın lokasyonlarda konumlanan dört alış veriş merkezi, evrensel tasarım prensipleri ve kullanıcı memnuniyeti (KM) açılarından değerlendirilerek karşılaştırılmıştır. Değerlendirmede, çok kriterli karar verme (ÇKKV) yapısından yararlanılmıştır. Bu yapıda, alış veriş merkezi alternatifleri, evrensel tasarım prensipleri ve $\mathrm{KM}$ ise kriterleri oluşturmaktadır. Bu 
kapsamda, Oran Analizi Temeline Dayalı Çok Amaçlı Optimizasyon (The Multi-Objective Optimization by Ratio Analysis MethodMOORA) yönteminin farklı versiyonlarının kullanılmasına karar verilmiştir. Bu amaçla, MOORA Oran, MOORA Referans Noktası yaklaşımları uygulanmıştır. Böylece, birden fazla farklı ÇKKV yaklaşımı ile alışveriş merkezleri için elde edilen sıralamaların geçerliliği de analiz edilmiştir. MOORA, Brauers ve Zavadskas (2006) tarafından geliştirilmiştir. MOORA yöntemi ve farklı versiyonlarının çalışmada tercih edilmesinin sebepleri, basit matematiksel bir işlem sürecine sahip olmaları, sübjektif ağırlıklı normalleştirme yerine sübjektif olmayan yönsüz değerler kullanmaları, literatürde yaygın olarak kullanılmalarıdır. Ayrıca MOORA, farklı yaklaşımları içermesi nedeniyle alternatif sıralamalarının karşılaştırılabilmesini de sağlamaktadır.

Her karar probleminde olduğu gibi, alışveriş merkezlerinin değerlendirilmesinde de uzman görüşleri alternatif sıralamalarını etkilemektedir. Gerçek hayattaki karar problemlerinde genellikle, karar konusuyla ilgili yeterli düzeyde bilgi ve deneyime sahip birkaç uzmanın görüşlerinden yararlanılarak sonuca ulaşılmaktadır. Ancak, uzmanların sayısı arttıkça, farklı görüşlere sahip uzmanların da karar sürecinde yer alabileceği bilinen bir gerçektir. Bu nedenle, her bir uzman, kararı etkileyebilecek farklı bir bakış açısı ortaya koyabilir. Uzman sayısı artarsa, MOORA ile değerlendirme sürecinin performansı da artacaktır. Geleneksel MOORA'da kriterlerin ağırlıkları ve alternatiflerin sıralanması birkaç uzman tarafından gerçekleştirilir ve rassallığın beraberinde getirdiği belirsizlik özelliği dikkate alınmaz. Bununla birlikte, gerçek hayattaki karar süreçlerinde belirsizlik hakimdir. Geleneksel MOORA'da kullanılan kesin skalalar, söz konusu belirsizliği modelleyemezler. Ayrıca, MOORA kendi içerisinde bir ağırlıklandırma prosedürü de uygulamamaktadır. Kriter ağırlıkları, farklı yöntemlerden elde edilir. Buna göre çalışmada, sürekli düzgün dağılımdan yararlanılarak MOORA yöntemi geliştirilmiştir. Sürekli düzgün dağılımın kullanılmasıyla; uzmanların değerlendirmelerindeki belirsizlik modellenerek, uzman sayısına bağımlılık ta ortadan kaldırılmıştır. Ayrıca, yine sürekli düzgün dağılım temelinde bir algoritma oluşturularak MOORA'da kriter ağırlıklarının da hesaplanması sağlanmıştır. Böylece, geliştirilmiş MOORA hem kriter ağırlığı hesaplayabilen hem de alternatif sıralamalarını belirleyebilen bir formata dönüştürülmüştür. Sürekli düzgün dağılım, belirli bir aralıkta yer alan her bir değerin ortaya çıkma şansının eşit olması nedeniyle tercih edilmiştir. Bu durum, farklı uzman görüşlerinin her birine eşit şans verilmesi anlamını taşımaktadır. Ayrıca, çalışmada kullanılan 1-5 skalası için de, ara değerler (1,2 veya 4,9 vb.) sürekli düzgün dağılım ile elde edilebilmektedir. Böylece, belirsizlik te modellenebilmektedir. Gerçek hayatta bir uzman değerlendirme yaparken örneğin; 1 ile 2 skoru arasında kararsız kalabilir. Bu belirsizlikten ötürü, rassallık meydana gelir ve kesin skalalar rassallık sonucu oluşan belirsizlikleri değerlendirmede başarısız olurlar. Buna göre, sınırlı sayıda uzmanın görüşleri kullanılarak, sürekli düzgün dağılımla rastgele sayılar üretilip; kriter ve alternatiflerin değerlendirmelerine ilişkin sonuçlar arttırılabilir. Buna göre, uzman sayısı da arttırılmış olacaktır. Her bir farklı değerlendirme, bir uzmanı temsil etmektedir. Rastgele sayılar, mevcut uzmanların en yüksek ve en düşük değerlendirmeleri dikkate alınarak, söz konusu aralıkta üretilir. Önerilen yöntem öznel olarak değerlendirmenin yapıldığı tüm karar süreçlerine uygulanabilir.

Çalışmanın kalan bölümlerinin organizasyonu ise şu şekildedir. İkinci bölümde MOORA ve evrensel tasarıma ilişkin literatür çalışmasına yer verilmiştir. Üçüncü bölümde, önerilen yaklaşımın algoritması ve uygulama süreci bir arada sunulmuştur. Dördüncü bölümde, elde edilen bulgular anlatılmış, beşinci bölümde, tartışma, altıncı bölümde ise sonuçlara değinilmiştir.

\section{Bilimsel Yazın Taraması}

Aslaksen, Bergh, Bringa ve Heggem (1997), profesyoneller ve politikacılar için evrensel tasarım uygulamaları hakkında bilgi vermeyi amaçlamıştır. Vanderheiden ve Tobias (2000) kapsamlı görüşmeler ve kapsamlı bir anket uygulaması yaparak evrensel tasarıma ilişkin kilit niteliğindeki kolaylaştırma stratejilerinin etkilerinin izlenmesini sağlamıştır. Beecher ve Paquet (2005), ürünlerin, tüketicilerin bakış açılarından evrensel tasarım ilkelerine ne kadar uygun olduğunu araştırmak için kullanılabilirlik testi şeklinde bir anket geliştirmişlerdir. Afacan ve Erbug (2009), mevcut bina tasarım pratiğinin kullanılabilirliğini evrensel tasarım prensipleri açısından analiz etmek için sezgisel değerlendirmeyi kullanmışlardır. Mackelprang ve Clute (2009), evrensel erişim kavramını ve felsefesini, istihdam başarısını arttırmada bir planlama paradigması olarak tanımlamışlardır. Imrie (2012), evrensel tasarım ilkelerinin kuramsal ve kavramsal bileşenlerini tartışarak eksik yönlerini belirlemiştir. Pittman ve Heiselt (2014), evrensel tasarım ilkelerini, sezgisel değerlendirmeyi kullanarak; engelli öğrenciler için çevrimiçi öğrenme ortamında uygulamaya koymuşlardır. Steen-Hansen, Lundh ve Chen (2014), 3D baskı programlarının ara yüzlerinin kullanılabilirliğini evrensel tasarım prensiplerini dikkate alarak değerlendirmişlerdir. Swaine, Labbé, Poldma, Barile, Fichten, Havel ve Rochette (2014) alışveriş merkezlerine sosyal katılımın önündeki engeller açısından evrensel kullanılabilirliği değerlendirmişlerdir. Myerson ve West (2015), sağlık hizmeti alabilmek için yapılması gerekenleri evrensel tasarım prensipleri açısından incelemişlerdir. Liu, You, Lin ve Li (2015) ve Liu, Lee, Kascak ve Sanford (2015), evrensel tasarım prensiplerine uygun bir oylama sistemi geliştirmişlerdir. Rieh ve Lee (2016), ilköğretim okulları için iç ve dış tasarım ilkelerini, evrensel tasarım açısından karşılaştırmışıı. Yılmaz Kaya ve Dağdeviren (2016), iş güvenliği ekipmanları seçiminde evrensel tasarım ilkelerini göz önüne alan bir ÇKKV çalışması gerçekleştirmişlerdir. Mustaquim and Nyström (2017), sürdürülebilir bilgi teknolojileri sistemini evrensel tasarım ilkeleri açısından değerlendirmiştir. Mustaquim ve Nyström (2017), evrensel tasarımın bazı özelliklerinin sürdürülebilirlik için yeniden tasarım stratejisi olarak kullanılabileceğini belirtmişlerdir. Meşhur ve Tekin (2018), evrensel tasarımı şehir planlama disiplini bakış açısı ile değerlendirerek, farklı bireylerin kent hayatında yaşadıkları sorunlar üzerinde durmuşlardır. Ökten (2018) tarafından, engelli kullanıcıların ihtiyaçlarına özel, üniversite kampüslerinin tasarımları üzerinde durulmuştur. Hahn, Nattapon, Dilinazi, Jiang ve Takahashi (2018), çöp bidonlarının tasarımlarını evrensel tasarım prensiplerine göre inceleyerek, farklı atıklar için insanların her bir çöp kutusu açısından psikolojik tercihlerini belirlemişlerdir. Terece (2019) tarafından, bir alışveriş merkezinin fiziki konfor ölçütlerinin evrensel tasarıma uygunluğu tespit edilmiş, fiziksel konfor bilincini etkileyen ve fiziksel konfor bilincini oluşturan faktörler belirlenmiştir.

MOORA yöntemi açısından literatür incelendiğinde ise, yöntemin farklı versiyonları kullanılarak gerçekleştirilen birçok çalışma olduğu görülmüştür. Bu kapsamda, geçmiş dönemlerde yapılan çalışmalardan örneklere yer verilmekle birlikte ağırlıklı olarak; Türkçe ve yabancı literatürde 2018-2019 yıllarına ait çalışmalar incelenmiştir. Karande ve Chakraborty (2012), ERP yazılımı seçiminde 
Bulanık MOORA (Fuzzy MOORA-F-MOORA) yöntemini uygulamıştı. Archana ve Sujatha (2012), en iyi ağ bağlantısını seçmek için F-MOORA-Gray entegrasyonunu önermişlerdir. Vatansever ve Uluköy (2013), bir şirket için Bulanık Analitik Hiyerarşi Süreci (Fuzzy Analytic Hierarchy Process-F-AHP) ve F-MOORA yöntemlerini kullanarak ERP yazılım sistemini seçmişlerdir. Baležentis ve Baležentis (2014), MULTIMOORA ve MOORA yöntemleri için bir anket çalışması yapmıştır. MOORA ve MULTIMOORA yöntemlerinin yaygın olarak teknolojik gelişme ve ekonomik araştırmalar için mühendislik karar desteği kapsamında kullanıldığını belirlemişlerdir. Akkaya, Turanoğlu ve Öztaş (2015), endüstri mühendisliği öğrencileri ve mezunlarının sektör seçimlerini F-AHP ve F-MOORA kullanarak araştırmışlardır. Akhavan, Barak, Maghsoudlou ve Antuchevičienè (2015), Bulanık Ek Katılma Oranı Değerlendirmesi (Fuzzy Additive Ratio Assessment-ARAS-F), Bulanık Karmaşık Oransal Değerlendirme (Complex Proportional Assessment-F-COPRAS), F-MOORA ve Bulanık İdeal Çözümle Benzerliğe göre Sipariş Tercihi Tekniği (Fuzzy Technique for Order Preference by Similarity to Ideal Solution-F-TOPSIS) kullanarak stratejik ortak seçimi için sistematik bir yaklaşım önermişlerdir. Bu dört yöntemin sonuçlarını birleştirmek için Borda yöntemi kullanmışlardır. Zavadskas, Antucheviciene, Razavi Hajiagha ve Hashemi (2015), aralık değerli sezgisel bulanık kümeleri ve MOORA'yı, mühendislikte grup karar verme alanında belirsizliği etkin bir şekilde modellemek için birleştirmişlerdir. Stanujkic (2016), MOORA yönteminin oran sistemi yaklaşımının aralık-değerli üçgensel bulanık sayıları kullanarak geliştirilmesini önermiştir. Ohlan (2016), sezgisel bulanık ortamlarda ÇKKV problemlerini çözmek için sezgisel bulanık üstel bir ayrıştırma ölçümünü önererek TOPSIS ve MOORA yöntemlerinin kullanılmasıyla karşılaştırmalı bir çalışma yürütmüştür. Stanujkic, Zavadskas, Smarandache, Brauers and Karabasevic (2017), nötrosofik kümelere dayanan yeni bir MULTIMOORA yöntemi geliştirmişlerdir. Atalay ve Can (2018), sezgisel bulanık AHP (Intiutionistic Fuzzy AHP-IF-AHP) ve sezgisel bulanık MOORA'yı (Intiutionistic Fuzzy MOORA-IF-MOORA) birleştiren, yeni ürün seçimi için yeni bir hibrid yaklaşım önermişlerdir. Oral, Karagöz, Tecim ve Ergül (2019) tarafından, Linux tabanlı fiziksel bir sunucu içerisinde 4 adet sanal sunucu oluşturulmuş ve her bir sunucuya aynı öğrenim yönetim sistemi kurulmuştur. Gelen istemcilerin bu 4 sanal sunucuya yönlendirilmesi amaçlanmıştır. Bu yönlendirmeyi yaparken, COPRAS, MOORA ve TOPSIS yöntemlerinden yararlanan bir ara yüz inşa edilmiştir. Yönetici, bu 3 yöntemden herhangi birini seçerek dağıtım işlemlerini gerçekleştirebilmektedir. Karar kriterleri olarak; sunucunun bellek kullanımı, CPU kullanımı ve sunucu içerisindeki anlık kişi sayısı seçilmiştir. Önerilen bu yöntemle, anlık kullanıcı yoğunluklarının ortaya çıkardığı dezavantajlı durumlar giderilmiştir. Karayel, Atmaca, Yalçın ve Burçak (2018), savunma sanayinde yer alan bir firmanın üretim bölümündeki taşıma problemlerine çözüm üretmek ve uygun taşıma yönteminin seçimini amaçlamışlardır. Üretimi aksatan problemleri ortadan kaldırmak amacıyla öncelikle imalat ortamına özgü olarak taşımada önem arz eden kriterler (araç kapasitesi, satın alma maliyeti, taşıma hassasiyeti, araç hızı, üretim ortamına uygulanabilirlik, taşıma kolaylığı, bakım-onarım sıklı̆ıı, ergonomi olmak üzere sekiz farklı kriter) belirlenmiş ve kriterlerin önem ağırlıkları AHP ile hesaplanmıştır. Sonrasında ise, yine imalat ortamına uygun dört farklı taşıma alternatifi (el arabası, römorklu çekici tren, çatallı yük arabası ve otomatik yönlendirmeli araçlar) belirlenerek; bu alternatifler içerisinden en uygun olanın seçimi Vise Kriterijumska Optimizacija I Kompromisno Resenje (VIKOR) ve MOORA yöntemleri kullanılarak yapılmıştır. Canbazoğlu, Ercan ve Çetin (2018), 667 adet ticari taksi alternatifinin sıralamasını yapabilecek, android ve IOS işletim sistemine sahip, cep telefonu ve tabletlerden kolaylıkla ulaşılabilen bir karar destek sisteminin mobil uygulamasını tasarlamışlardır. Mobil uygulamada kriter ağırlıklandırma için AHP, ticari araçları sıralamak için MOORA tekniği kullanılmıştır. Bircan, Arslan, ve Eleroğlu (2018), Kayseri bölgesinde açığa çıkan hayvansal (büyükbaş ve kanatlı hayvan gübresi) ve kesimhane atıklarının değerlendirilmesi için kurulan biyogaz tesislerinin optimal uygunluk sıralamalarının yapılması amacıyla MOORA ve COPRAS yöntemlerini kullanmışlardır. Konak, Elbir, Yılmaz, Karataş, Durman ve Düzakın (2018), 2010-2015 döneminde, hisse senetleri Borsa İstanbul (BIST)'da işlem gören ve tekstil sektöründe faaliyette bulunan 23 şirketin finansal performanslarının karşılaştırılması için bu şirketlere ait mali tablolardan elde edilen veriler kapsamında belirlenen 10 kriteri esas alarak; TOPSIS ve MOORA yöntemleriyle firmaların sıralamasını elde etmişlerdir. Analiz sonucunda, tekstil sektöründe faaliyette bulunan şirketlerin performans puanlarının 2014 analiz döneminde genel olarak benzerlik gösterdiği tespit edilmiştir. Ömürbek ve Eren (2019), gıda sektöründe faaliyet gösteren bir firmanın 13 finansal oran çerçevesinde, 2005-2014 yılları arasındaki performansını PROMETHEE, MOORA ve COPRAS yöntemleri ile değerlendirmiş ve yıllara göre firmaların sıralaması her üç yönteme göre yapılarak karşıllaştırılmıştır. Performans değerlendirilmesinde, cari oran, nakit oran, asit test oranı, stoklar/toplam aktif, öz kaynak/toplam aktif, borçlanma oranı, finansal kaldıraç oranı, öz kaynak karlılığı, net kar marjı, fiyat kazanç oranı, net çalışma sermayesi devir hızı, stok devir hızı ve alacak devir hızı kriterleri dikkate alınmıştır. Çalışmanın sonucunda, en iyi performans yılının 2014 olduğu görülmüsstür. Orhan ve Kenger (2018), Osmaniye ilinde uzun zamandır faaliyet gösteren yerel bir zincir market için işe alınacak personelin seçiminde F-AHP ve F-MOORA yöntemlerini uygulayarak; en uygun tercihi yapmaya çalışılmışlardır. Çelikbilek (2018), personel seçimi için bütünleşik Gri AHP-MOORA yaklaşımı önerisinde bulunmuştur. Gri sayıların tercih edilmesinin nedeni, kişisel yargıları temsil yeteneğindeki başarısı ve seçimler sırasında, kişisel yargılardan kaynaklı yanlılıkların minimize edilerek işlemlere dahil edilmesidir. Pérez-Domínguez (2018), Pisagor bulanık kümeleri ile MOORA yöntemini birleştirmiştir ve önerilen yaklaşımın uygulanabilirliğini iki farklı karar problemi üzerinde göstermiştir. Arabsheybani, Paydar ve Safaei (2018), Hata Türü ve Etkileri Analizi (Failure Modes and Effects Analysis-FMEA) ile F-MOORA'y1, miktar indirimleri ve tedarikçinin riskini de göz önünde bulundurarak sürdürülebilir tedarikçi seçimi için birleştirmişlerdir. Chawla, Agrawal ve Singari (2019), MOORA ve TOPSIS yöntemlerini kullanarak; müşteri ihtiyaçlarına göre en iyi bisikleti müşteri bakış açısıyla belirlemişlerdir. Erdoğdu (2018), Türkiye'de faaliyet gösteren beş katılım bankasının finansal performanslarını, 2016 ve 2017 yılları aralığında, 3 aylık bilanço rasyolarını dikkate alarak MULTIMOORA Tekniği ile analiz etmiştir. Gümüş (2019), çalışmasında, ulaştırma sektöründe faaliyet gösteren işletmelerin finansal performanslarını, VIKOR ve MOORA yöntemleri ile analiz etmiştir. Karakaş ve Kırmızı (2019), MOORA (Oran ve Referans Noktası yaklaşımları) ve TOPSIS yöntemlerini kullanarak; Kuzey Hazar Denizi'nde çalışmak amacıyla en uygun olan AHT gemisinin seçimini gerçekleştirmişlerdir. Söz konusu üç yöntemin ürettiği sonuçlar arasındaki uyum, Kendall'ın Eşleşme Katsayısı (Kendall'ın W) tarafından test edilmiştir. Kuşakçı, Ayvaz, Öztürk ve Sofu (2019), personel seçimi sürecindeki belirsizliği ve sübjektifliği dikkate alarak; problemin çözümü için bulanık MULTIMOORA metodunu önermişlerdir. Havacılık sektöründe faaliyet gösteren bir firmada gerçekleştirilen bu çalışmada, İnsan kaynakları uzmanları ile yapılan görüşmeler sonucunda ortaya çıkan veriler kullanılarak; MULTIMOORA yöntemiyle en iyi aday belirlenmeye çalışılmıştır. Bulguların 
geçerliliğini test etmek ve önerilen yöntemin kullanışlılı̆ını değerlendirmek amacıyla adaylar, ayrıca bütünleşik AHP-TOPSIS yöntemi ile değerlendirilmiş ve iki modelin aynı sonucu verdiği görülmüştür. İç (2019) tarafından, ticari bankacıllkta sıkça karşılaşılan şirketler için kredi borç verme karar verme problemlerini çözmek için MOORA ve hedef programlama entegrasyonuna dayanan çok amaçlı bir optimizasyon modeli önerilmiştir. Ghoushchi, Yousefi ve Khazaeili (2019), FMEA tekniğinin bazı eksik yönlerinin geliştirilmesi amacıyla üç aşamalı bir yaklaşım önermişlerdir. Birinci aşamada, FMEA, hata türlerini tanımlamak ve Risk Öncelik Numarasını (RPN) belirlemek için kullanılmıştır. İkinci aşamada, uzmanların görüşlerine dayanan Bulanık En İyi En Kötü Yöntemi (Fuzzy Best-Worst Method-FBWM) faktörlerin ağırlıklarını belirlemek için kullanılmıştır. Üçüncü aşamada, önceki iki aşamanın çıktıları, Z sayı teorisine dayanan Oran Analizi (Z-MOORA) ile Çok Amaçlı Optimizasyon kullanılarak hata türleri önceliklendirilmiştir. Hanifatulqolbi, Ismail, Hammad ve Al-Hooti (2019) tarafindan, MOORA yönteminin kullanılmasıyla öğretmen performanslarının değerlendirilmesi için web tabanlı bir karar destek sistemi geliştirilmiş̧ir.

Evrensel tasarım ve MOORA'ya ilişkin gerçekleştirilen çalışmalardan da görüldüğü gibi; MOORA yönteminin işleyiş prosedürüne ilişkin herhangi bir geliştirme çalışması bugüne kadar yapılmamış olup, evrensel tasarım prensipleri ve KM dikkate alınarak alışveriş merkezleri ÇKKV yaklaşımları ile değerlendirilmemiştir. Bu açılardan, yapılan çalışma literatüre katkı sağlayabilecek bir orijinalliktedir. Çalışmanın alışveriş merkezi inşalarına farklı bir bakış açısı getirerek, bu merkezlerin yöneticilerinin yapılar, kamunun hizmetine sunulduğu an itibariyle oluşabilecek ihtiyaçları daha farklı şekilde görebilmeleri konusunda da destek sağlayabileceği değerlendirilmektedir. Bununla birlikte, sürekli düzgün dağıllım kullanılarak MOORA yönteminin geliştirilmesi kapsamında da herhangi bir çalışmanın bulunmadığı da belirlenmiştir. Bu açıdan da yapılan çalışma, MOORA yöntemini fonksiyonel olarak da daha güçlü bir hale getirmektedir.

\section{Materyal ve Uygulama}

Bu bölümde, sürekli düzgün dağılım kullanılarak geliştirilen MOORA yönteminin farklı versiyonlarına ilişkin önerilen algoritma ile ilgili algoritmanın uygulandığı, evrensel tasarım prensipleri ve KM dikkate alınarak en iyi alışveriş merkezinin belirlenmesi probleminin çözümüne yer verilmiştir.

\section{Birinci aşama: Sürekli düzgün dağılım kullanılarak kriter önem ağırıklarının hesaplanması}

\section{Adım 1: Kriterleri ve alternatifleri belirleyerek uzman grubunu oluştur.}

Kriterler, alternatifleri sıralarken dikkate alınacak ölçütleri oluşturmaktadır ve $K_{j} ; j=1, \ldots, J$ ile ifade edilir. Alternatifler ise, uzmanların seçim portföyünü oluşturan unsurlardır ve $A_{i} ; i=1, \ldots, I$ olarak tanımlanılar. Uzman grubunu, karar probleminin konusuna bağlı olarak, deneyim ve bilgi sahibi kişiler oluşturmaktadır. Söz konusu kişiler, karar vericilerdir ve bu grup $U_{l} ; l=1, \ldots, L$ ile gösterilir.

Çalışmada, dört alışveriş merkezi evrensel tasarım prensipleri ve KM dikkate alınarak değerlendirilmiştir. Bu kapsamda, karar problemi dört alternatiften $A_{i} ; i=1,2,3,4$ ve sekiz kriterden $K_{j} ; j=1, \ldots, 8$ oluşmaktadır. Bu kriterler, EK $\left(K_{1}\right), \operatorname{KE}\left(K_{2}\right)$, BSK $\left(K_{3}\right)$, AB $\left(K_{4}\right)$, HT $\left(K_{5}\right)$, DFGG $\left(K_{6}\right)$, YKUBM $\left(K_{7}\right)$ ve KM $\left(K_{8}\right)$ 'dir. Uzman grubu ise, üç karar vericiden $U_{l} ; l=1,2,3$ meydana gelmektedir. Söz konusu uzmanlardan birincisi, 8 yıllık iş deneyimine sahip bir iç mimar, diğeri 15 yıllık iş deneyimine sahip bir inşaat mühendisi, sonuncusu ise 22 yıllık iş deneyimine sahip bir şehir planlamacısıdır. Üç uzmanın da ortak özelliği, daha önce büyük alışveriş merkezi inşaatlarında çalışmış olmalarıdır. KM'yi değerlendirmek için uzmanlara, alışveriş merkezleri ile ilgili gerçekleştirebilecekleri beş farklı görev verilerek; sonrasında bu görevleri gerçekleștirirken alışveriş merkezi alan tasarımlarından ne kadar memnun kaldıklarını Tablo 2'deki skalayı kullanarak belirlemeleri istenmiş̧tir. Uzmanlara verilen görevler aşağıda Tablo 1'de sunulmaktadır.

Tablo 1. Uzmanlara verilen görevler

\begin{tabular}{c|l}
\hline Görev Numarası & \multicolumn{1}{c}{ Görev Tanımı } \\
\hline 1 & $\begin{array}{l}\text { Asansörü kullanarak an alt kata } \\
\text { ininiz. }\end{array}$ \\
\hline 2 & $\begin{array}{l}\text { Arabanızı kapalı otoparka park } \\
\text { ediniz. }\end{array}$ \\
\hline 3 & $\begin{array}{l}\text { Alışveriş merkezinin çıkış ve giriş } \\
\text { kapılarını kullanınız. }\end{array}$ \\
\hline 4 & $\begin{array}{l}\text { Alışveriş merkezindeki } \\
\text { bankomatları bulunuz. }\end{array}$ \\
\hline 5 & $\begin{array}{l}\text { Yürüyen merdivenleri kullanarak } \\
\text { en üst kata çıkınız. }\end{array}$ \\
\hline
\end{tabular}


Dört alışveriş merkezinde de, yüzün üzerinde mağaza, otopark, çocuklar ve yetişkinler için etkinlik alanları, yemek alanı, bankalar, acil durumlar için tıbbi birimler, bebek arabaları, ödemeli telefonlar, kasalar, bebek bakım odaları, danışma masaları, kablosuz internet erişimi vs. imkanlar bulunmaktadır. Birinci alışveriş merkezi $\left(A_{1}\right), 50.000 \mathrm{~m}^{2}$ 'lik bir alana, 150 'den fazla mağazaya ve 2300 araç kapasiteli bir otoparka sahiptir. İkinci alışveriş merkezi $\left(A_{2}\right), 75.760 \mathrm{~m}^{2}$ 'lik bir alana, 180 'den fazla mağazaya ve 2600 araç kapasiteli bir otoparka sahiptir. Üçüncü alışveriş merkezi $\left(A_{3}\right), 80.000 \mathrm{~m}^{2}$ 'lik bir alana, 230 adet mağazaya ve 1700 araç kapasiteli bir otoparka sahiptir. Dördüncü alışveriş merkezi $\left(A_{4}\right), 25.560 \mathrm{~m}^{2}$ 'lik alana, 250 mağazaya ve 2200 araç kapasiteli bir otoparka sahiptir.

\section{Adım 2. Kriterlerin önem düzeylerini belirle.}

Her bir uzman, her bir kriteri Tablo 2'de verilen skalayı kullanarak önem düzeylerine göre değerlendirir.

Tablo 2. Değerlendirme skalası

\begin{tabular}{c|l}
\hline Skor & Açıklama \\
\hline 1 & Çok önemsiz/Hiç memnun değilim \\
\hline 2 & Önemsiz/Memnun değilim \\
\hline 3 & Orta derecede önemli/Orta düzeyde memnunum \\
\hline 4 & Önemli/Memnunum \\
\hline 5 & Çok önemli/Çok memnunum \\
\hline
\end{tabular}

Her bir uzmanın kriterlere ilişkin önem düzeyi değerlendirmesi $x_{l j}$ ( $l$. uzmanın $j$. kritere atadığ önem) olarak ifade edilir. Üç uzmanın kriterler için gerçekleştirdikleri değerlendirmeler Tablo 3 ‘de sunulmaktadır.

Tablo 3. Üç uzmanın kriterlerin önem düzeylerine ilişkin değerlendirmeleri

\begin{tabular}{c|c|c|c}
\hline & $\boldsymbol{U}_{\mathbf{1}}$ & $\boldsymbol{U}_{\mathbf{2}}$ & $\boldsymbol{U}_{\mathbf{3}}$ \\
\hline $\boldsymbol{K}_{\boldsymbol{j}}$ & $x_{1 j}$ & $x_{2 j}$ & $x_{3 j}$ \\
\hline$K_{1}$ & 5 & 5 & 3 \\
\hline$K_{2}$ & 4 & 3 & 2 \\
\hline$K_{3}$ & 5 & 3 & 4 \\
\hline$K_{4}$ & 3 & 2 & 1 \\
\hline$K_{5}$ & 4 & 3 & 3 \\
\hline$K_{6}$ & 4 & 2 & 2 \\
\hline$K_{7}$ & 5 & 4 & 3 \\
\hline$K_{8}$ & 4 & 1 & 2 \\
\hline
\end{tabular}

\section{Adım 3. Kriterlerin önem düzeyleri için maksimum ve minimum değerleri belirle.}

Her bir kriter için bütün uzmanların yaptıkları değerlendirmeler dikkate alınarak; en yüksek önem değeri olan $\left(x_{j}\right)_{\max }$ ve en düşük önem değeri olan $\left(x_{j}\right)_{\min }$ belirlenir. Alışveriş merkezlerini değerlendirmek için dikkate alınan kriterlere ait $\left(x_{j}\right)_{\max }$ ve $\left(x_{j}\right)_{\min }$ değerleri Tablo 4’te verilmiştir. 
European Journal of Science and Technology

Tablo 4. Kriterlerin önem düzeylerine ilişkin $\left(x_{j}\right)_{\min }$ ve $\left(x_{j}\right)_{\max }$ değgerleri

\begin{tabular}{c|c|c}
\hline $\boldsymbol{K}_{\boldsymbol{j}}$ & $\left(\boldsymbol{x}_{\boldsymbol{j}}\right)_{\min }$ & $\left(\boldsymbol{x}_{\boldsymbol{j}}\right)_{\max }$ \\
\hline$K_{1}$ & 3 & 5 \\
\hline$K_{2}$ & 2 & 4 \\
\hline$K_{3}$ & 3 & 5 \\
\hline$K_{4}$ & 1 & 3 \\
\hline$K_{5}$ & 2 & 4 \\
\hline$K_{6}$ & 2 & 4 \\
\hline$K_{7}$ & 2 & 5 \\
\hline$K_{8}$ & 1 & 4 \\
\hline
\end{tabular}

\section{Adım 4. Alternatiflerin kriterlere göre performans değerlerini belirle.}

Her bir uzman, her bir alternatifi, her bir kritere göre Tablo 2'de verilen skalayı kullanarak değerlendirir. Bu değerlendirmeler, $y_{l i j}$ olarak tanımlanır. Aşağıda yer alan Tablo 5 'te birinci uzmanın, alternatifler için belirlediği performans değerleri yer almaktadır.

Tablo 5. Birinci uzmana ait $y_{1 i j}$ değerleri

\begin{tabular}{r|r|r|r|r|r|r|r|r}
\hline \multirow{2}{*}{$\boldsymbol{A}_{\boldsymbol{i}}$} & \multicolumn{1}{|c}{$\boldsymbol{K}_{\boldsymbol{j}}$} \\
\cline { 2 - 9 } & \multicolumn{1}{|c|}{$K_{1}$} & \multicolumn{1}{c}{$K_{2}$} & \multicolumn{1}{c}{$K_{3}$} & \multicolumn{1}{c}{$K_{4}$} & \multicolumn{1}{c}{$K_{5}$} & \multicolumn{1}{c}{$K_{6}$} & \multicolumn{1}{c}{$K_{7}$} & $K_{8}$ \\
\cline { 2 - 9 } & $y_{1 i 1}$ & $y_{1 i 2}$ & $y_{1 i 3}$ & $y_{1 i 4}$ & $y_{1 i 5}$ & $y_{1 i 6}$ & $y_{1 i 7}$ & $y_{1 i 8}$ \\
\hline$A_{1}$ & 5 & 3 & 1 & 3 & 5 & 3 & 4 & 1 \\
\hline$A_{2}$ & 3 & 2 & 2 & 5 & 3 & 3 & 2 & 2 \\
\hline$A_{3}$ & 2 & 5 & 2 & 4 & 4 & 2 & 3 & 4 \\
\hline$A_{4}$ & 5 & 2 & 3 & 3 & 3 & 3 & 5 & 3 \\
\hline
\end{tabular}

Adım 5. Alternatiflere ait performans değerlerinin maksimum ve minimumunu belirle.

Her bir uzmanın belirlediği alternatif performans değerleri dikkate alınarak, her bir alternatif için en yüksek ve en düşük performans değerleri belirlenir. Bu değerler sırasıyla $\left(y_{i j}\right)_{\max }$ ve $\left(y_{i j}\right)_{\min }$ olarak ifade edilir. Aşağıda, Tablo 6'da alternatiflere ilişkin sirasıyla $\left(y_{i j}\right)_{\max }$ ve $\left(y_{i j}\right)_{\min }$ değerleri yer almaktadır. 
Tablo 6. Her bir alternatif için en yüksek ve en düşük performans değeri

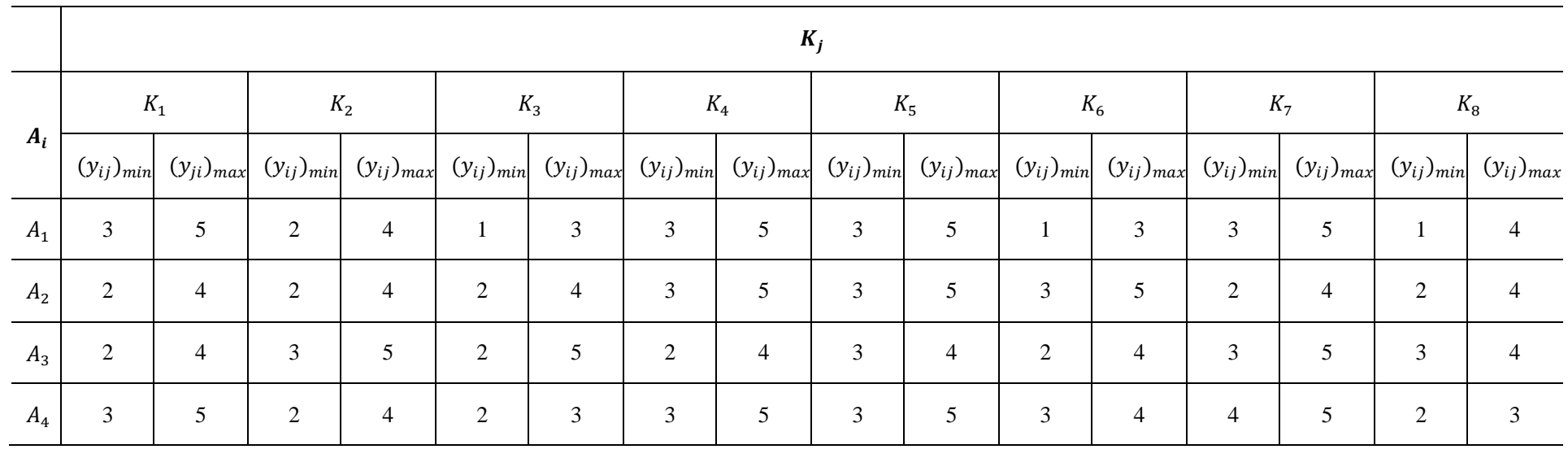

\section{Adım 6. Kriterler için rastgele sayıları üret ve satır toplamı al.}

Her bir kriter için $\left(x_{j}\right)_{\min }$ ve $\left(x_{j}\right)_{\max }$ arasında, sürekli düzgün dağılımdan 30 tane rastgele sayı üretilir. Burada, uzmanların belirledikleri en yüksek önem düzeyi ve en düşük önem düzeyi arasında kalmak şartıyla uzman sayısı 30'a çıkarılmaktadır. Tablo 7'de, bütün kriterler için üretilen rastgele sayılar ve satır toplamları yer almaktadır.

Tablo 7. Kriterler için üretilen rastgele sayllar ve satır toplamları

\begin{tabular}{|c|c|c|c|c|c|c|c|c|c|}
\hline \multirow{2}{*}{$U_{l}$} & $K_{1}$ & $K_{2}$ & $K_{3}$ & $K_{4}$ & $K_{5}$ & $K_{6}$ & $K_{7}$ & $K_{8}$ & \multirow{2}{*}{$\sum_{j=1}^{8} x_{l j}$} \\
\hline & $x_{l 1}$ & $x_{l 2}$ & $x_{l 3}$ & $x_{l 4}$ & $x_{l 5}$ & $x_{l 6}$ & $x_{l 7}$ & $x_{l 8}$ & \\
\hline$U_{1}$ & 4,136 & 3,785 & 4,456 & 2,464 & 2,690 & 3,048 & 4,908 & 1,345 & 26,832 \\
\hline$U_{2}$ & 4,097 & 2,847 & 4,758 & 2,269 & 2,965 & 2,973 & 2,147 & 1,762 & 23,818 \\
\hline$U_{3}$ & 3,706 & 2,348 & 4,462 & 2,580 & 2,985 & 3,832 & 3,452 & 2,005 & 25,370 \\
\hline$U_{4}$ & 4,802 & 2,162 & 4,616 & 2,445 & 2,451 & 2,445 & 4,208 & 2,641 & 25,770 \\
\hline$U_{5}$ & 4,451 & 2,377 & 3,959 & 1,594 & 3,127 & 2,607 & 2,930 & 2,090 & 23,135 \\
\hline$U_{6}$ & 4,465 & 2,003 & 4,467 & 2,079 & 3,269 & 3,553 & 2,536 & 1,697 & 24,069 \\
\hline$U_{7}$ & 4,702 & 3,506 & 3,348 & 1,699 & 3,108 & 3,976 & 4,501 & 3,981 & 28,821 \\
\hline$U_{8}$ & 4,016 & 2,726 & 3,501 & 1,499 & 3,568 & 2,917 & 2,500 & 3,615 & 24,342 \\
\hline$U_{9}$ & 4,345 & 2,010 & 3,297 & 1,980 & 2,567 & 3,457 & 4,462 & 3,997 & 26,115 \\
\hline$U_{10}$ & 3,451 & 2,991 & 4,655 & 2,191 & 3,145 & 2,877 & 4,048 & 3,712 & 27,070 \\
\hline$U_{11}$ & 3,247 & 2,709 & 3,819 & 2,938 & 3,986 & 2,836 & 4,155 & 1,463 & 25,153 \\
\hline$U_{12}$ & 3,616 & 2,154 & 4,212 & 1,826 & 2,236 & 2,102 & 4,822 & 3,402 & 24,370 \\
\hline$U_{13}$ & 4,471 & 2,707 & 4,130 & 2,946 & 3,045 & 2,390 & 4,714 & 2,636 & 27,039 \\
\hline$U_{14}$ & 4,934 & 2,031 & 4,888 & 2,188 & 3,637 & 3,359 & 3,969 & 3,405 & 28,411 \\
\hline$U_{15}$ & 4,907 & 2,379 & 3,009 & 2,999 & 2,336 & 2,654 & 2,468 & 3,864 & 24,616 \\
\hline$U_{16}$ & 3,734 & 3,602 & 4,061 & 2,498 & 2,329 & 3,700 & 3,222 & 3,613 & 26,759 \\
\hline
\end{tabular}


European Journal of Science and Technology

\begin{tabular}{c|c|c|c|c|c|c|c|c|c}
\hline$U_{17}$ & 3,641 & 3,904 & 4,371 & 2,550 & 2,805 & 2,620 & 4,838 & 2,487 & 27,216 \\
\hline$U_{18}$ & 3,187 & 3,312 & 4,593 & 2,334 & 2,626 & 2,805 & 4,969 & 3,243 & 27,069 \\
\hline$U_{19}$ & 4,215 & 2,260 & 4,688 & 2,639 & 2,160 & 2,754 & 2,913 & 2,891 & 24,520 \\
\hline$U_{20}$ & 3,347 & 2,722 & 3,645 & 1,144 & 2,551 & 2,875 & 2,038 & 3,779 & 22,101 \\
\hline$U_{21}$ & 3,092 & 2,403 & 4,274 & 2,811 & 2,140 & 2,984 & 4,371 & 1,877 & 23,952 \\
\hline$U_{22}$ & 3,094 & 3,440 & 3,943 & 1,073 & 3,659 & 3,504 & 4,329 & 2,598 & 25,640 \\
\hline$U_{23}$ & 4,169 & 3,869 & 4,500 & 2,382 & 3,652 & 3,946 & 2,678 & 1,018 & 26,214 \\
\hline$U_{24}$ & 3,112 & 3,550 & 3,004 & 2,063 & 2,925 & 3,394 & 4,332 & 2,277 & 24,657 \\
\hline$U_{25}$ & 3,185 & 2,942 & 3,208 & 1,909 & 2,241 & 2,153 & 2,879 & 3,585 & 22,102 \\
\hline$U_{26}$ & 4,292 & 3,841 & 3,186 & 2,393 & 3,184 & 2,258 & 2,886 & 3,555 & 25,595 \\
\hline$U_{27}$ & 4,040 & 3,180 & 3,235 & 2,353 & 3,865 & 2,720 & 2,789 & 2,158 & 24,340 \\
\hline$U_{28}$ & 4,480 & 3,667 & 3,630 & 2,662 & 2,091 & 3,602 & 3,160 & 2,960 & 26,252 \\
\hline$U_{29}$ & 3,646 & 2,691 & 3,494 & 2,506 & 2,680 & 2,191 & 3,828 & 2,603 & 23,639 \\
\hline$U_{30}$ & 4,286 & 3,708 & 4,783 & 2,745 & 2,861 & 3,726 & 4,762 & 1,809 & 28,680 \\
\hline$w_{j}$ & 0,156 & 0,115 & 0,158 & 0,089 & 0,114 & 0,118 & 0,143 & 0,108 & 0,156 \\
\hline & & & & & & & & &
\end{tabular}

Adım 7. Kriterler için üretilen rastgele sayıların satır normalizasyonunu yap ve kriter önem ağırlıklarını hesapla.

Sürekli düzgün dağılımdan üretilen 30 tane rastgele sayının satır normalizasyonu Eşitlik (1) kullanılarak yapılır ve kriter önem ağırlıkları hesaplanır.

$x_{l j}{ }^{*}=\frac{x_{l j}}{\sum_{j=1}^{J} x_{l j}}$

Burada;

$x_{l j}{ }^{*} ; l$. uzmanın $j$. kritere ilişkin normalize önem değeridir.

Her bir kriter için $x_{l j}{ }^{*}$ değerlerinin ortalaması, Eşitlik (2)'deki gibi alınarak, kriter önem ağırlıkları $w_{j}$ elde edilir. $w_{j}$ değerleri Tablo 7'de gösterilmektedir.

$w_{j}=\frac{\sum_{j=1}^{J} x_{l j}{ }^{*}}{L} ; \sum_{j=1}^{J} w_{j}=1$

\section{Adım 8. Alternatifler için rastgele sayıları üret ve başlangıç karar matrisini oluştur.}

Her bir alternatif için $\left(y_{i j}\right)_{\min }$ ve $\left(y_{i j}\right)_{\max }$ arasında, sürekli düzgün dağılımdan, 30 tane rastgele sayı üretilir. Burada, uzmanların belirledikleri en yüksek önem düzeyi ve en düşük önem düzeyi arasında kalmak şartıyla uzman sayısı 30'a çıkarılmaktadır. 30 uzmanın, her bir alternatif için kriterler kapsamında belirledikleri performans değerlerinin ortalaması $\bar{y}_{i j}$ alınarak, söz konusu uzmanların görüşleri birleştirilir. Tablo 8 'de $A_{1}$ için, bütün kriterler dikkate alınarak üretilen rastgele sayılar ve sütun ortalamaları örnek olarak yer almaktadır. Sütun ortalamaları alternatiflerin herbir kriter için performans değerlerini göstermektedir. 
Avrupa Bilim ve Teknoloji Dergisi

Tablo 8. $A_{1}$ için üretilen rastgele sayılar ve sütun ortalamaları

\begin{tabular}{|c|c|c|c|c|c|c|c|c|}
\hline \multirow{2}{*}{$U_{l}$} & $K_{1}$ & $K_{2}$ & $K_{3}$ & $K_{4}$ & $K_{5}$ & $K_{6}$ & $K_{7}$ & $K_{8}$ \\
\hline & $y_{l 11}$ & $y_{l 12}$ & $y_{l 13}$ & $y_{l 14}$ & $y_{l 15}$ & $y_{l 16}$ & $y_{l 17}$ & $y_{l 18}$ \\
\hline$U_{1}$ & 4,979 & 3,638 & 1,007 & 4,579 & 4,566 & 2,487 & 3,006 & 2,082 \\
\hline$U_{2}$ & 3,103 & 2,306 & 2,717 & 4,244 & 3,071 & 2,007 & 4,422 & 2,347 \\
\hline$U_{3}$ & 3,918 & 2,734 & 1,356 & 3,863 & 3,897 & 2,797 & 3,324 & 2,867 \\
\hline$U_{4}$ & 3,333 & 2,882 & 2,601 & 4,854 & 3,891 & 2,822 & 4,520 & 3,112 \\
\hline$U_{5}$ & 3,301 & 3,459 & 1,448 & 3,444 & 3,635 & 1,325 & 4,755 & 2,400 \\
\hline$U_{6}$ & 4,790 & 3,210 & 1,421 & 3,941 & 3,775 & 1,269 & 3,121 & 2,442 \\
\hline$U_{7}$ & 4,966 & 3,811 & 2,869 & 4,142 & 4,959 & 1,852 & 3,116 & 2,935 \\
\hline$U_{8}$ & 3,429 & 2,442 & 2,219 & 3,759 & 3,034 & 2,896 & 3,061 & 2,640 \\
\hline$U_{9}$ & 4,020 & 3,307 & 2,644 & 4,795 & 4,160 & 2,077 & 3,837 & 3,687 \\
\hline$U_{10}$ & 3,145 & 3,101 & 1,295 & 4,240 & 3,305 & 1,367 & 4,341 & 2,412 \\
\hline$U_{11}$ & 4,621 & 3,409 & 2,475 & 4,756 & 3,637 & 2,375 & 4,692 & 3,380 \\
\hline$U_{12}$ & 3,627 & 3,501 & 2,043 & 3,486 & 4,554 & 2,647 & 3,246 & 1,322 \\
\hline$U_{13}$ & 4,930 & 3,124 & 2,242 & 4,133 & 3,695 & 2,961 & 3,401 & 2,146 \\
\hline$U_{14}$ & 3,254 & 3,541 & 2,940 & 4,220 & 4,063 & 2,529 & 3,980 & 2,167 \\
\hline$U_{15}$ & 4,423 & 3,181 & 2,385 & 3,919 & 3,859 & 1,922 & 4,740 & 2,241 \\
\hline$U_{16}$ & 4,364 & 2,615 & 1,560 & 3,271 & 3,267 & 2,496 & 3,200 & 2,061 \\
\hline$U_{17}$ & 3,445 & 2,365 & 2,912 & 3,195 & 3,551 & 1,363 & 3,025 & 3,165 \\
\hline$U_{18}$ & 3,850 & 3,746 & 2,633 & 3,497 & 4,495 & 2,288 & 4,852 & 3,610 \\
\hline$U_{19}$ & 4,728 & 3,405 & 1,637 & 3,185 & 3,975 & 1,219 & 4,359 & 1,578 \\
\hline$U_{20}$ & 4,548 & 2,773 & 2,255 & 3,910 & 4,767 & 1,943 & 3,070 & 1,352 \\
\hline$U_{21}$ & 3,841 & 3,108 & 2,599 & 3,548 & 3,754 & 1,808 & 3,703 & 2,846 \\
\hline$U_{22}$ & 4,208 & 3,431 & 2,019 & 3,947 & 4,394 & 1,442 & 4,237 & 2,585 \\
\hline$U_{23}$ & 3,530 & 3,558 & 2,920 & 3,799 & 3,123 & 1,202 & 3,691 & 1,883 \\
\hline$U_{24}$ & 3,462 & 2,404 & 2,303 & 3,828 & 4,735 & 1,031 & 3,827 & 2,604 \\
\hline$U_{25}$ & 4,289 & 2,542 & 2,054 & 4,031 & 4,581 & 1,266 & 4,181 & 2,570 \\
\hline$U_{26}$ & 3,102 & 3,883 & 1,907 & 4,396 & 4,631 & 1,127 & 4,104 & 2,177 \\
\hline$U_{27}$ & 4,205 & 3,849 & 1,818 & 4,397 & 3,446 & 1,508 & 4,588 & 1,775 \\
\hline
\end{tabular}


European Journal of Science and Technology

\begin{tabular}{c|c|c|c|c|c|c|c|c}
\hline$U_{28}$ & 3,249 & 2,692 & 1,410 & 3,012 & 4,343 & 2,454 & 4,414 & 1,471 \\
\hline$U_{29}$ & 4,531 & 2,055 & 1,231 & 4,802 & 4,287 & 2,530 & 4,246 & 2,904 \\
\hline$U_{30}$ & 4,739 & 3,761 & 1,203 & 3,483 & 4,227 & 1,116 & 4,817 & 3,648 \\
\hline $\bar{y}_{1 j}$ & 3,998 & 3,128 & 2,071 & 3,956 & 3,989 & 1,938 & 3,929 & 2,480 \\
\hline
\end{tabular}

Her bir alternatif için $\bar{y}_{i j}$ değerleri birleştirilerek başlangıç karar matrisi $[B]$ oluşturulur. Dört alışveriş merkezinin kriterlere göre performans değerlerinin bulunduğu $[B]$, Tablo 9'da verilmiştir.

Tablo 9. Başlangıç karar matrisi

\begin{tabular}{c|c|c|c|c|c|c|c|c}
\hline \multirow{2}{*}{$\boldsymbol{A}_{\boldsymbol{i}}$} & $\boldsymbol{K}_{\mathbf{1}}$ & $\boldsymbol{K}_{\mathbf{2}}$ & $\boldsymbol{K}_{\mathbf{3}}$ & $\boldsymbol{K}_{\mathbf{4}}$ & $\boldsymbol{K}_{\mathbf{5}}$ & $\boldsymbol{K}_{\mathbf{6}}$ & $\boldsymbol{K}_{\mathbf{7}}$ & $\boldsymbol{K}_{\mathbf{8}}$ \\
\cline { 2 - 8 } & $\bar{y}_{i 1}$ & $\bar{y}_{i 2}$ & $\bar{y}_{i 3}$ & $\bar{y}_{i 4}$ & $\bar{y}_{i 5}$ & $\bar{y}_{i 6}$ & $\bar{y}_{i 7}$ & $\bar{y}_{i 8}$ \\
\hline$A_{1}$ & 3,998 & 3,128 & 2,071 & 3,956 & 3,989 & 1,938 & 3,929 & 2,480 \\
\hline$A_{2}$ & 2,906 & 2,910 & 2,873 & 4,040 & 3,925 & 4,004 & 3,000 & 3,034 \\
\hline$A_{3}$ & 2,884 & 3,989 & 3,648 & 3,087 & 3,406 & 2,894 & 4,010 & 3,496 \\
\hline$A_{4}$ & 3,948 & 3,043 & 2,623 & 4,009 & 4,172 & 3,528 & 4,511 & 2,431 \\
\hline
\end{tabular}

\section{Adım 9. Başlangıç karar matrisini MOORA yöntemini uygulayarak normalize et.}

Başlangıç karar matrisi $[B]$, MOORA prosedürüne uygun olarak; Eşitlik (3)'ün kullanılmasıyla normalize edilir ve normalize başlangıç karar matrisi $[N]$, elde edilir. $[N]$ 'in her bir elemanı $y_{i j}^{*}$ ile tanımlanır. Alışveriş merkezleri için normalize başlangıç karar matrisi Tablo 10'da sunulmaktadır.

$$
y_{i j}^{*}=\bar{y}_{i j} / \sqrt{\sum_{i=1}^{I}\left(\bar{y}_{i j}\right)^{2}}, j=1,2, \ldots, J
$$

Tablo 10. Normalize başlangıç karar matrisi

\begin{tabular}{c|c|c|c|c|c|c|c|c}
\hline \multirow{2}{*}{$\boldsymbol{A}_{\boldsymbol{i}}$} & $\boldsymbol{K}_{\mathbf{1}}$ & $\boldsymbol{K}_{\mathbf{2}}$ & $\boldsymbol{K}_{\mathbf{3}}$ & $\boldsymbol{K}_{\mathbf{4}}$ & $\boldsymbol{K}_{\mathbf{5}}$ & $\boldsymbol{K}_{\mathbf{6}}$ & $\boldsymbol{K}_{\mathbf{7}}$ & $\boldsymbol{K}_{\mathbf{8}}$ \\
\cline { 2 - 9 } & $y_{i 1}^{*}$ & $y_{i 2}^{*}$ & $y_{i 3}^{*}$ & $y_{i 4}^{*}$ & $y_{i 5}^{*}$ & $y_{i 6}^{*}$ & $y_{i 7}^{*}$ & $y_{i 8}^{*}$ \\
\hline$A_{1}$ & 0,575 & 0,475 & 0,362 & 0,521 & 0,514 & 0,304 & 0,504 & 0,429 \\
\hline$A_{2}$ & 0,418 & 0,442 & 0,502 & 0,532 & 0,505 & 0,628 & 0,385 & 0,524 \\
\hline$A_{3}$ & 0,415 & 0,605 & 0,638 & 0,407 & 0,438 & 0,454 & 0,514 & 0,604 \\
\hline$A_{4}$ & 0,568 & 0,462 & 0,458 & 0,528 & 0,537 & 0,554 & 0,578 & 0,420 \\
\hline
\end{tabular}

\section{Adım 10. Ağırlıklı normalize karar matrisini oluştur.}

Adım 7'de hesaplanan $w_{j}$ değerleri ile $y_{i j}^{*}$ değerleri çarpılarak; ağılıklı normalize karar matrisi $[K]$ elde edilir. $[K]$ 'nın her bir elemanı $y_{i j}^{\prime}$ ile tanımlanır. Alışveriş merkezlerine ait $[K]$, Tablo 11 'de verilmektedir. 
Tablo 11. Ağırllkll Normalize karar matrisi

\begin{tabular}{c|c|c|c|c|c|c|c|c}
\hline \multirow{2}{*}{$\boldsymbol{A}_{\boldsymbol{i}}$} & $\boldsymbol{K}_{\mathbf{1}}$ & $\boldsymbol{K}_{\mathbf{2}}$ & $\boldsymbol{K}_{\mathbf{3}}$ & $\boldsymbol{K}_{\mathbf{4}}$ & $\boldsymbol{K}_{\mathbf{5}}$ & $\boldsymbol{K}_{\mathbf{6}}$ & $\boldsymbol{K}_{\mathbf{7}}$ & $\boldsymbol{K}_{\mathbf{8}}$ \\
\cline { 2 - 9 } & $y_{i 1}^{\prime}$ & $y_{i 2}^{\prime}$ & $y_{i 3}^{\prime}$ & $y_{i 4}^{\prime}$ & $y_{i 5}^{\prime}$ & $y_{i 6}^{\prime}$ & $y_{i 7}^{\prime}$ & $y_{i 8}^{\prime}$ \\
\hline$A_{1}$ & 0,090 & 0,055 & 0,057 & 0,046 & 0,059 & 0,036 & 0,072 & 0,046 \\
\hline$A_{2}$ & 0,065 & 0,051 & 0,079 & 0,047 & 0,058 & 0,074 & 0,055 & 0,057 \\
\hline$A_{3}$ & 0,065 & 0,070 & 0,100 & 0,036 & 0,050 & 0,054 & 0,073 & 0,065 \\
\hline$A_{4}$ & 0,089 & 0,053 & 0,072 & 0,047 & 0,061 & 0,065 & 0,083 & 0,045 \\
\hline
\end{tabular}

\section{Adım 11. MOORA Oran, MOORA referans noktası yöntemlerini uygulayarak alternatif sıralamalarını belirle.}

MOORA Oran yönteminde Eşitlik (4) kullanılarak her bir alternatifin tercih değeri, $t_{i}{ }^{*}$ hesaplanır ve alternatifler $t_{i}{ }^{*}$ değerlerine göre büyükten küçüğe doğru sıralanırlar.

$$
t_{i}^{*}=w_{j} \sum_{j=1}^{g} y_{i j}^{*}-w_{j} \sum_{j=g+1}^{J} y_{i j}^{*}
$$

Burada, $j=1, \ldots, g$ fayda türü kriterleri, $j=g+1, \ldots, J$ maliyet türü kriterleri göstermektedir. Çalışmada dikkate alınan kriterlerin hepsi fayda türü kriterler oldukları için $\sum_{j=g+1}^{J} y_{i j}^{*}=0$ alınmıştır.

MOORA referans yönteminde, Eşitlik (5) kullanılarak her bir alternatifin tercih değeri $t_{i}{ }^{*}$ hesaplanır ve alternatifler $t_{i}{ }^{*}$ değerlerine göre büyükten küçüğe doğru sıralanırlar. Burada kriterler fayda yapılı ise, alternatifler arasında her bir kriter için belirlenen en yüksek performans değeri belirlenir. Maliyet yapılı kriterler için ise, alternatiflerin aynı kriter için aldıkları performans değerleri arasındaki en küçük değer belirlenir. Daha sonra, her bir kriter için her bir alternatifin performans değeri fayda türü bir kriterse maksimum değerden, maliyet türü bir kriter ise minimum değerden çıkarılır. Söz konusu maksimum ve minimum değerler, referans noktaları, $r_{i j}$ olarak tanımlanır. Alternatifler $t_{i}{ }^{*}$ değerlerine göre küçükten büyüğe doğru sıralanır.

$$
t_{i}^{*}=\min _{j}\left\{\max _{i}\left(w_{j}\left|r_{i j}-y_{i j}^{*}\right|\right)\right\}
$$

Alışveriş merkezlerinin MOORA oran ve MOORA referans yöntemlerine göre sıralamaları Tablo 12'de verilmektedir.

Tablo 12. MOORA Oran ve MOORA Referans Noktası Yöntemlerine Göre Sıralama Sonuçları

\begin{tabular}{c|c|c|c|c}
\hline $\boldsymbol{A}_{\boldsymbol{i}}$ & $\boldsymbol{t}_{\boldsymbol{i}}{ }^{*}$ & $\begin{array}{c}\text { Önem } \\
\text { Katsayisi } \\
\text { MOORA } \\
\text { Oran }\end{array}$ & $\boldsymbol{t}_{\boldsymbol{i}}{ }^{*}$ & $\begin{array}{c}\text { Önem } \\
\text { Katsayisı } \\
\text { MOORA } \\
\text { Referans }\end{array}$ \\
\hline$A_{1}$ & 0,460 & 4 & $9,02707 \mathrm{E}-11$ & 4 \\
\hline$A_{2}$ & 0,486 & 3 & $1,64257 \mathrm{E}-10$ & 3 \\
\hline$A_{3}$ & 0,513 & 2 & $2,09436 \mathrm{E}-10$ & 2 \\
\hline$A_{4}$ & 0,515 & 1 & $2,38601 \mathrm{E}-10$ & 1 \\
\hline
\end{tabular}

\section{Araştırma Sonuçları}

Çalışmada, sürekli düzgün dağılım kullanılarak MOORA yöntemi kapsamındaki iki farklı yaklaşımın uygulanmasıyla; dört farklı alı̧veriş merkezi, sekiz kritere göre değerlendirilmiştir. Elde edilen sonuçlara göre, uzmanların alışveriş merkezleri açısından en önemli gördükleri kriterin BSK $\left(K_{3}\right)(0,158)$ kriteri olduğu belirlenmiştir. En düşük önem ağırlığına sahip olan kriterin ise, $\mathrm{AB}\left(K_{4}\right)$ $(0,089)$ kriteri olduğu ortaya çıkmıştır. Bununla birlikte, MOORA Oran ve MOORA Referans Noktası yaklaşımlarına göre, alışveriş merkezlerinin sıralamalarında herhangi bir farklılaşma olmamışırı. Her iki yaklaşıma göre, dördüncü alışveriş merkezi $\left(A_{4}\right)$ dikkate alınan kriterler açısından en iyi alışveriş merkezi olarak belirlenmiştir. Aynı şekilde, birinci alışveriş merkezi $\left(A_{1}\right)$, kriterler açısından en az tercih edilen alışveriş merkezi olmuştur. 


\section{Sonuç ve Tartışma}

Çalışmada sürekli düzgün dağılım desteğiyle geliştirilen iki farklı MOORA yaklaşımında da $A_{4}$ en iyi alternatif olarak belirlenmiştir. Bu sonuç, uzmanlar tarafindan da mantıklı bir sonuç olarak görülmüş̧ür. Çünkü dördüncü alışveriş merkezi diğer alternatiflere göre daha küçük ancak konum olarak daha merkezi bir yerde bulunmaktadır. Söz konusu alışveriş merkezinde, mağazalar daha organize bir şekilde yerleştirilmiştir ve asansörler ile yürüyen merdivenler arasındaki mesafeler daha kısadır. Bununla birlikte, daha fazla yürüyen merdiven ve asansöre sahiptir. Asansörler daha geniştir ve yürüyen merdivenlerde sensörler vardır. Asansörlerde işitsel ve yazılı olmak üzere iki farklı uyarı sistemi bulunmaktadır. Bütün bu özellikler, uzmanlar açısından dördüncü alışveriş merkezini en iyi alternatif yapmıştır. Alışveriş merkezinin daha küçük bir alana sahip olması kullanımını da kolaylaştıran bir etki olarak ortaya çıkmıştır. Çalışmada, en önemli kriter olarak belirlenen BSK kriterini de, söz konusu alışveriş merkezi özellikleriyle desteklemektedir.

Çalışmada, sürekli düzgün dağılımın MOORA kapsamındaki iki farklı yaklaşım için kullanılması, hem birkaç karar vericinin değerlendirmesine bağllık durumunu ortadan kaldırmış hem de uzman değerlendirmelerindeki belirsizliğin modellenebilmesini de sağlamıştır. Böylece, uzmanların kesin değerli skalalara bağlı kalmadan ara değerleri de kullanabilmeleri sağlanmıştır. Uzman sayısının arttırılmasıyla birlikte, karar konusuna ilişkin farklı değerlendirmeler de dikkate alınabilmiştir. Bununla birlikte, iki farklı yaklaşımın da aynı sıralama sonuçlarını vermesi, önerilen sürekli düzgün dağılım temelli MOORA yönteminin mantıklı ve stabil sonuçlar üretebildiğini de göstermektedir. Çalışmanın, alışveriş merkezlerinin tercih edilme durumlarına ilişkin dikkate aldığ kriterler ve uygulanan yöntemler açısından yeni bir bakış açısı sağladığı değerlendirilmektedir.

Gelecek dönem çalışmalarında, sürekli düzgün dağılım, farklı ÇKKV yöntemlerine uygulanabilir. Uzman değerlendirmelerine uygun olabilecek farklı dağılımlar kullanılabilir ve sonuçlar karşılaştırılabilir.

\section{Kaynakça}

Afacan, Y., \& Erbug, C. (2009). An interdisciplinary heuristic evaluation method for universal building design. Applied Ergonomics, 40(4), 731-744.

Akhavan, P., Barak, S., Maghsoudlou, H., \& Antuchevičienė, J. (2015). FQSPM-SWOT for strategic alliance planning and partner selection; case study in a holding car manufacturer company. Technological and Economic Development of Economy, 21(2), 165185.

Akkaya, G., Turanoğlu, B., \& Öztaş, S. (2015). An integrated fuzzy AHP and fuzzy MOORA approach to the problem of industrial engineering sector choosing. Expert Systems with Applications, 42(24), 9565-9573.

Arabsheybani, A., Paydar, M. M., \& Safaei, A. S. (2018). An integrated fuzzy MOORA method and FMEA technique for sustainable supplier selection considering quantity discounts and supplier's risk. Journal of cleaner production, 190, 577-591.

Archana, M., \& Sujatha, V. (2012). Application of fuzzy moora and gra in multi-criterion decision making problems. International Journal of Computer Applications, 53(9).

Aslaksen, F., Bergh, S., Bringa, O. R., \& Heggem, E. K. (1997). Universal design: Planning and design for all.

Atalay, K. D., \& Can, G. F. (2018). A new hybrid intuitionistic approach for new product selection. Soft Computing, 22(8), 2633-2640.

Baležentis, T., \& Baležentis, A. (2014). A survey on development and applications of the multi-criteria decision making method MULTIMOORA. Journal of Multi-Criteria Decision Analysis, 21(3-4), 209-222.

Beecher, V., \& Paquet, V. (2005). Survey instrument for the universal design of consumer products. Applied Ergonomics, 36(3), 363372.

Bircan, H., Arslan, R., \& Eleroğlu, H. (2018, October). MOORA ve COPRAS yöntemleriyle Kayseri ilinde kurulabilecek biyogaz tesislerinin optimallik siralamas1. In ICPESS (International Congress on Politic, Economic and Social Studies) (No. 5).

Brauers, W. K., \& Zavadskas, E. K. (2006). The MOORA method and its application to privatization in a transition economy. Control and Cybernetics, 35, 445-469.

Canbazoğlu, E., Ercan, U., \& Çetin, E. İ. (2018). ticari taksi araç yenilemelerinde ahs ve moora yöntemlerine dayalı karar destek mobil uygulamasi. Uluslararası Iktisadi ve İdari Incelemeler Dergisi, 117-134.

Chawla, S., Agrawal, S., \& Singari, R. M. (2019). Integrated TOPSIS-MOORA Model for Prioritization of New Bike Selection. In Advances in Engineering Design (pp. 755-765). Springer, Singapore.

Çelikbilek, Y. (2018). Personel Seçimi için Bütünleşik Gri AHP-MOORA Yaklaşımının Kullanılması: Sağlık Sektöründe Yönetici Seçimi Üzerine Bir Uygulama. Alphanumeric Journal, 6(1), 69-82.

Erdoğdu, A. (2018). Katılım Bankalarının Performans Analizlerine MULTIMOORA Yöntemi ile Bir Bakış. Ekonomi, Yönetim ve Sosyal Araştırmalar Dergisi, 3(2), 99-111.

Ghoushchi, S. J., Yousefi, S., \& Khazaeili, M. (2019). An extended FMEA approach based on the Z-MOORA and fuzzy BWM for prioritization of failures. Applied Soft Computing, 81, 105505.

Gümüş, U. T. (2019). bist'de işlem gören ulaştırma sektöründeki firmaların finansal performans analizleri: MOORA ve VIKOR uygulama. TURAN-SAM, 11(41), 275-284.

Hahn, J., Nattapon, L., Dilinazi, D., Jiang, Q., \& Takahashi, F. (2018). Potential Universal Design of Rubbish Bins for Visually Impaired People and Their Psychological Preference Analysis. In Proceedings of the Annual Conference of Japan Society of Material Cycles and Waste Management The 29th Annual Conference of Japan Society of Material Cycles and Waste Management (p. 527). Japan Society of Material Cycles and Waste Management. 
Hanifatulqolbi, D., Ismail, I. E., Hammad, J., \& Al-Hooti, M. H. (2019, April). Decision support system for considering the best teacher performance using MOORA method. In Journal of Physics: Conference Series (Vol. 1193, No. 1, p. 012018). IOP Publishing.

Imrie, R. (2012). Universalism, universal design and equitable access to the built environment. Disability and rehabilitation, 34(10), $873-882$.

İç, Y. T. (2019). A Multi-Objective Credit Evaluation Model Using MOORA Method and Goal Programming. Arabian Journal for Science and Engineering, 1-14.

Karande, P., \& Chakraborty, S. (2012). A Fuzzy-MOORA approach for ERP system selection. Decision Science Letters, 1(1), 11-21.

Karakaş, S., \& Kırmızı, M. (2019). Multı-purpose TUGBOAT/AHT selectıon for Northern Caspıan Sea wıth TOPSIS and MOORA methods. Journal of Naval Sciences and Engineering, 15(1), 21-38.

Karayel, S. D., Atmaca, E., Yalçın, C., \& Burçak, E. R. O. L. (2018). VIKOR ve MOORA yöntemleri ile malzeme taşıma sistemi seçimi. Uluslararası İktisadi ve İdari İncelemeler Dergisi, 695-708.

Konak, T., Elbir, G., Yılmaz, S., Karataş, B. M., Durman, Y., \& Düzakın, H. (2018). Borsa İstanbul'da İşlem Gören Tekstil Firmalarının TOPSIS ve MOORA Yöntemi ile Analizi. Çukurova Üniversitesi İktisadi ve İdari Bilimler Fakültesi Dergisi, 22(1), $11-44$.

Kuşakçı, A. O., Ayvaz, B., Öztürk, F., \& Feyza, S. O. F. U. Bulanık MULTIMOORA İle personel seçimi: havacılık sektöründe bir uygulama. Ömer Halisdemir Üniversitesi Mühendislik Bilimleri Dergisi, 8(1), 96-110.

Liu, H. C., You, J. X., Lin, Q. L., \& Li, H. (2015). Risk assessment in system FMEA combining fuzzy weighted average with fuzzy decision-making trial and evaluation laboratory. International Journal of Computer Integrated Manufacturing, 28(7), 701-714.

Liu, Y. E., Lee, S. T., Kascak, L. R., \& Sanford, J. A. (2015, August). The bridge connecting theory to practice-A case study of universal design process. In International Conference on Universal Access in Human-Computer Interaction (pp. 64-73). Springer, Cham.

Mackelprang, R. W., \& Clute, M. A. (2009). Access for all: universal design and the employment of people with disabilities. Journal of social work in disability \& rehabilitation, 8(3-4), 205-221.

Meşhur, H. F. A., \& Tekin, M. (2018). Evrensel Tasarım Yaklaşımının Şehir Planlama Disiplini Bakış Açısı ile Değerlendirilmesi. Online Journal of Art and Design, 6(5).

Meyer, A., \& Fourie, I. (2016). Make the makers' voices count: combining universal design and participatory ergonomics to create accessible makerspaces for individuals with (physical) disabilities. In 15th Eahil Conference, Spain.

Mustaquim, M. M., \& Nyström, T. (2017). Some aspects of using universal design as a redesign strategy for sustainability. In Advances and New Trends in Environmental Informatics (pp. 49-60). Springer, Cham.

Myerson, J., \& West, J. (2015). Make It Better: how universal design principles can have an impact on healthcare services to improve the patient experience.

Ohlan, A. (2016). Intuitionistic fuzzy exponential divergence: application in multi-attribute decision making. Journal of Intelligent \& Fuzzy Systems, 30(3), 1519-1530.

Oral, L. O., Karagöz, E., Tecim, V., \& Ergül, A. V. (2019). TOPSIS, MOORA ve COPRAS Tekniklerine Dayalı Etkin Sunucu Yönlendirme Sistemi: Mobil Uygulama.

Organ, A., \& Kenger, M. D. (2018). Bütünleşik Bulanık AHP-Bulanık MOORA Yaklaşımının Market Personeli Seçimi Problemine Uygulanması. Anemon Muş Alparslan Üniversitesi Sosyal Bilimler Dergisi, 6(ICEESS'18), 271-280.

Ökten, G. (2018). Evrensel Tasarım İlkeleri Doğrultusunda Engelsiz Üniversite Kampüslerinin Tasarlanması ve Biçimlenmesi Üzerine Bir Araştırma. Yüksek Lisans Tezi, Hacettepe Üniversitesi Güzel Sanatlar Fakültesi İç Mimarlık ve Çevre Tasarımı Bölümü.

Ömürbek, N., \& Eren, H. (2019). PROMETHEE, MOORA ve COPRAS Yöntemleri İle Oran Analizi Sonuçlarının Değerlendirilmesi: Bir Uygulama-Evaluation of the results of the rate analysis with PROMETHEE, MOORA and COPRAS Methods: An Application. Mehmet Akif Ersoy Üniversitesi Sosyal Bilimler Enstitüsü Dergisi, 8(16), 174-187.

Pérez-Domínguez, L., Rodríguez-Picón, L. A., Alvarado-Iniesta, A., Luviano Cruz, D., \& Xu, Z. (2018). MOORA under Pythagorean fuzzy set for multiple criteria decision making. Complexity.

Pittman, C. N., \& Heiselt, A. K. (2014). Increasing accessibility: Using Universal Design principles to address disability impairments in the online learning environment. Online Journal of Distance Learning Administration, 17(3), 1-11.

Rieh, S. Y., \& Lee, M. W. (2016). A study on the universal design in elementary school facilities-focused on analysis of design guidelines. The Journal of Korean Institute of Educational Facilities, 23(2), 19-29.

Stanujkic, D. (2016). An extension of the ratio system approach of MOORA method for group decision-making based on intervalvalued triangular fuzzy numbers. Technological and Economic Development of Economy, 22(1), 122-141.

Stanujkic, D., Zavadskas, E. K., Smarandache, F., Brauers, W. K., \& Karabasevic, D. (2017). A neutrosophic extension of the MULTIMOORA method. Informatica, 28(1), 181-192.

Steen-Hansen, L., Gine Lundh, M. V., \& Chen, W. (2014). How universal design principles can enhance the interface of 3D printing programs. In DS 78: Proceedings of the 16th International conference on Engineering and Product Design Education (E\&PDE14), Design Education and Human Technology Relations, University of Twente, The Netherlands, 04-05.09. 2014 (pp. 123-128).

Story, M. F. (1998). Maximizing usability: the principles of universal design. Assistive technology, 10(1), 4-12.

Swaine, B., Labbé, D., Poldma, T., Barile, M., Fichten, C., Havel, A., ... \& Rochette, A. (2014). Exploring the facilitators and barriers to shopping mall use by persons with disabilities and strategies for improvements: Perspectives from persons with disabilities, rehabilitation professionals and shopkeepers. ALTER-European Journal of Disability Research/Revue Européenne de Recherche sur le Handicap, 8(3), 217-229. 
Terece, T., \& Berkin, G. (2019). Alışveriş Merkezlerinde Evrensel Tasarım ve Konfor: İstanbul'da Geniş Programlı Bir Alışveriş Merkezi Deneyimi. FSM İlmi Araştırmalar Insan ve Toplum Bilimleri Dergisi, (13), 211-236.

Vanderheiden, G., \& Tobias, J. (2000, July). Universal design of consumer products: current industry practice and perceptions. In Proceedings of the human factors and ergonomics society annual meeting (Vol. 44, No. 32, pp. 6-19). Sage CA: Los Angeles, CA: SAGE Publications.

Yılmaz Kaya, B., \& Dağdeviren, M. (2016). Selecting occupational safety equipment by MCDM approach considering universal design principles. Human Factors and Ergonomics in Manufacturing \& Service Industries, 26(2), 224-242.

Zavadskas, E. K., Antucheviciene, J., Hajiagha, R., Hossein, S., \& Hashemi, S. S. (2015). The interval-valued intuitionistic fuzzy MULTIMOORA method for group decision making in engineering. Mathematical Problems in Engineering, 2015. 